\title{
Shingles on the Tongue
}

\author{
Kazuhisa Yokota $^{1}$, Yushi Chikasawa ${ }^{1}$, Yuri Kimura ${ }^{2}$ and Kohei Shirai ${ }^{2}$
}

Key words: shingles, HIV, tongue

(Intern Med 59: 1467, 2020)

(DOI: 10.2169/internalmedicine.3919-19)

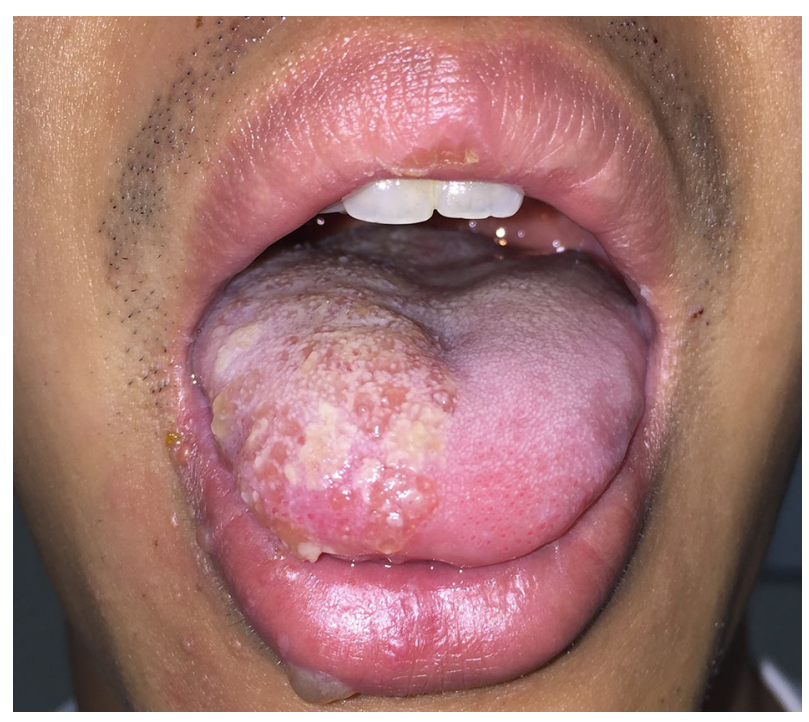

Picture.

A 26-year-old man with untreated HIV infection presented to our hospital with a 2-day history of pain on his tongue. Clusters of small blisters were found on his tongue and lower lip, but only on the right side (Picture). His HIV viral load was 18,000 copies/mL, and his CD4 cell count was 366 cells $/ \mu \mathrm{L}$. He took valacyclovir because we diagnosed him with mandibular shingles, but three days later, the shingles had spread to the auditory nerve in addition to the mandibular nerve (disseminated herpes zoster). In previously reported cases of oral shingles $(1,2)$, only 1 nerve was affected, and the cases were all over 50 years of age. Shingles is rare before 50 years of age (3), thus suggesting a decreased cellular immunity in this patient. This is even more so the case for patients with disseminated herpes zoster. While the present patient was already known to have HIV infection, in general, when we encounter patients with shingles under 50 years old, the possibility of HIV infection should be considered.

The authors state that they have no Conflict of Interest (COI).

\section{References}

1. Hagiya $\mathrm{H}$, Nakagami F, Isomura E. Oral shingles. BMJ Case Rep 11: e228383, 2018.

2. Kosami K, Kenzaka T. Mandibular herpes zoster. Intern Med 58: 459-460, 2019.

3. Yawn BP, Saddier P, Wollan PC, St Sauver JL, Kurland MJ, Sy LS. A population-based study of the incidence and complication rates of herpes zoster before zoster vaccine introduction. Mayo Clin Proc 82: 1341-1349, 2007.

The Internal Medicine is an Open Access journal distributed under the Creative Commons Attribution-NonCommercial-NoDerivatives 4.0 International License. To view the details of this license, please visit (https://creativecommons.org/licenses/ by-nc-nd/4.0/).

\footnotetext{
${ }^{1}$ Department of Laboratory Medicine, Tokyo Medical University Hospital, Japan and ${ }^{2}$ Department of Dermatology, Tokyo Medical University Hospital, Japan

Received: September 12, 2019; Accepted: November 20, 2019; Advance Publication by J-STAGE: January 9, 2020

Correspondence to Dr. Kazuhisa Yokota, yokota77@hotmail.com
}

(C) 2020 The Japanese Society of Internal Medicine. Intern Med 59: 1467, 2020 